\title{
Heterologous expression, purification and refolding of an anti-listerial peptide produced by Pediococcus acidilactici K7
}

\author{
Prakash M. Halami* \\ Department of Food Microbiology \\ Central Food Technological Research Institute \\ Mysore 570020 India \\ Tel: 918212517539 \\ Fax: 918212517233 \\ E-mail: foodmicro@cftri.res.in \\ Arun Chandrashekar \\ Department of Plant Cell Biotechnology \\ Central Food Technological Research Institute \\ Mysore 570020 India \\ Tel: 918212516501 \\ Fax: 918212517233 \\ E-mail: pcbt@cftri.res.in \\ Website: http://www.cftri.com
}

Financial support: This work was supported by the financial assistance obtained from the institute funds of CFTRI, Council of Scientific and Industrial Research, New Delhi. Government of India.

Keywords: fusion protein, inclusion bodies, in vitro refolding, pediocin PA-1, Pediococcus acidilactici, RP-HPLC.

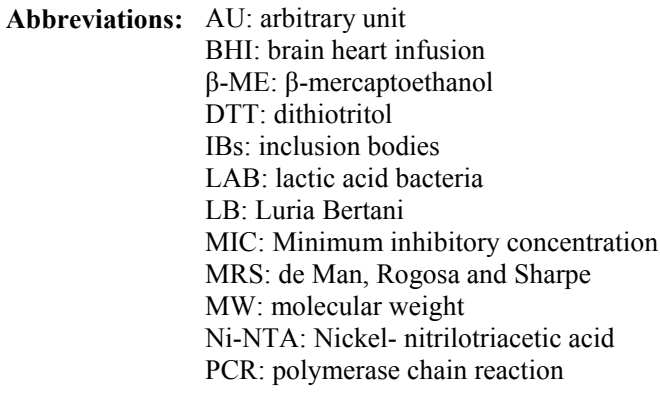

The fusion protein, 6 XHis-Xpress-PedA was constructed and expressed in Escherichia coli BL21 (DE3). The presence of a $12.8 \mathrm{kDa}$ recombinant protein, localized in inclusion bodies (IBs) at high concentration, was confirmed by SDS-PAGE analysis and by western blotting using anti-His antibody. The rec-pediocin was purified by Nickel-nitrilotriacetic acid beads and refolded using $5 \mathrm{mM}$ of $\beta$-mercaptoethanol along with 1 $M$ glycine. Results indicated that the refolded recpediocin had an early elution profile in the RP-HPLC when compared to the unfolded protein and it exhibited biological activity against Listeria monocytogenes $\mathrm{V} 7$ which was approximately 25 times less active compared to native counterpart. The final yield of purified recpediocin was $3 \mathrm{mg} / \mathrm{l}$ of the culture and is estimated to be 8-10 times higher than the purification by conventional methods.
Antilisterial bacteriocin, pediocin PA-1 produced by Pediococcus acidilactici displays a broad-spectrum bacteriocidal activity against many Gram-positive and certain stressed Gram-negative bacteria associated with food-spoilage and human pathogenesis. Bacteriocins of lactic acid bacteria (LAB) also have potential applications in controlling topical infections caused by bacterial pathogens (Miller et al. 1998; Rodriguez et al. 2003). For their characterization and applications, bacteriocins of $\mathrm{LAB}$ have been purified employing standard methods of purification, which involves more than 3-steps to achieve purification to homogeneity (Daba et al. 1994; Elegado et al. 1997). However, purification through these routine methods resulted in low levels of recovery and the possibility of the immunity protein remaining contaminated due to their similar molecular weight (MW) and possible in vitro interactions (Stein et al. 2003). The main difficulty in

*Corresponding author 


\section{MRGSHHHHHHGM ASMTGGQQMG RDLYDDODKD RWGSELEICS}

YLANASRFFA MEKIEKLTEK EMANIIGGK+1Y YGNGVTCGKH SCSVDWGKAT

TCIINNGAMA WATGGHQGNH KC+44-
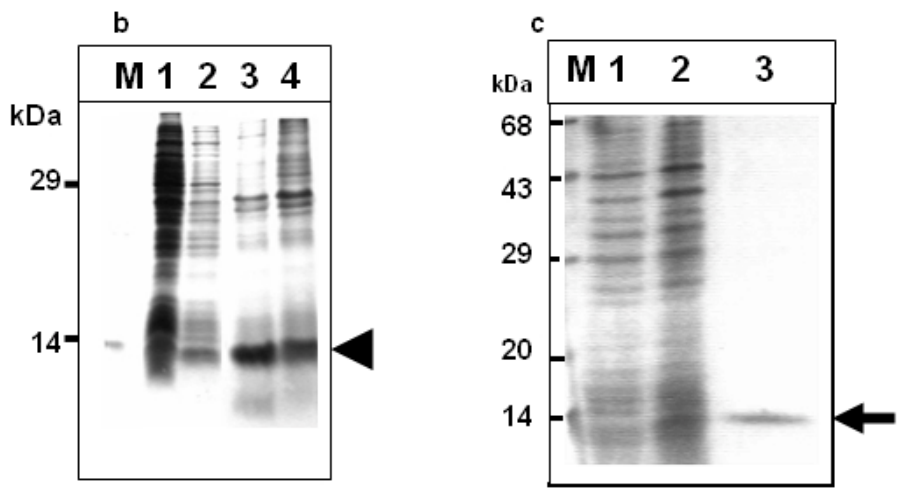

Figure 1. Construction, expression and purification of rec-pediocin.

a) Deduced amino acid sequences of the recombinant pre-pediocin. Authentic portion of the sequences are shown in bold. The added tags are in italics and changed nucleotide primers generated aa in bold italics.

b) SDS-PAGE (15\% acrylamide) gel analysis of IBs purified from hyper expressing $E$. coli. Lane 1 , whole cell lysate from induced cells. Lane 2, 3 \& 4 are IBs washed with 2, 4 and $6 \mathrm{M}$ urea. $\mathrm{M}$, is medium range protein marker (Bangalore Genei). Arrow indicates the position of $12.8 \mathrm{kDa}$ rec-pediocin.

c) Single step purification of rec-pediocin. Gel analysis of $6 \mathrm{X}$ histidine -Xpress-prepediocin produced in $E$. coli. Lane 1 , total cell lysate uninduced; 2, Lysate, induced recombinant and lane 3, Ni-NTA beads absorbed IBs protein eluted with $0.5 \mathrm{M}$ immidazole. M, protein marker. Arrow indicates purified rec-pediocin.

exploiting bacteriocins commercially is the low production rates in their native conditions. Hence, heterologous systems can offer a better insight for elevated production (Makrides, 1996). Pediocin PA-1 has been heterologously expressed in several strains of $E$. coli, P. pentosaceus, Lactococcus lactis, Lactobacillus sakei and yeast. The antimicrobial activity of heterologously expressed pediocin PA-1 varied from approximately $25 \%$ less than that of the wild type (WT) to 2.5 fold higher depending on the expression system (Marugg et al. 1992; Axelsson et al. 1998; Coderre and Somkuti, 1999; Somkuti and Steinberg, 2003; Reviriego et al. 2005). While expressing the pediocin PA-1 in LAB, it is important to know that many of the LAB are naturally sensitive to pediocin PA-1. In such cases, pedA has to be expressed in combination with the immunity protein pedB (Axelsson et al. 1998; Moon et al. 2005).

Heterologous systems for the bacteriocin proteins not only facilitate higher levels of expression but also help obtaining pure form of the molecules (Makrides, 1996; Rodriguez et al. 2003). Expression of biologically active form of recombinant pediocin (rec-pediocin) using heterologous system in a soluble form remains a bottle neck. The expression system for pediocin PA-1 that are reported in literature such as MBP in E. coli, resulted in considerably low yield of rec-pediocin (Miller et al. 1998; Ray et al. 1999). Attempts made to express pediocin PA-1 in yeast, where active disulfide-bond formation takes place, showed low levels of expression (Schoeman et al. 1999) and inhibition of biological activity (Beaulieu et al. 2005). Richard et al. (2004) expressed synthetic gene of divericin V41 in the origami strain of $E$. coli that favors disulfide bond formation in the cytosol. Pediocin PA-1 being a low MW peptide with two disulfide-bridges, may tend to accumulate in inclusion bodies (IBs) of $E$. coli upon overexpression in case of reduced condition of cytosol. Thus, proteins expressed in IBs of $E$. coli need subsequent isolation, purification, solubilization and refolding in suitable redox systems to achieve biological activity (Rogl et al. 1998; Patra et al. 2000; Winter et al. 2002a).

Although pediocin PA-1 has been heterologously expressed in other genera, the study on expression and purification systems for pediocin PA-1 in E. coli has made slow progress (Moon et al. 2006). Expression and purification of biologically active rec-pediocin PA-1 from $E$. coli has been described, however accumulation in IBs of $E$. coli and refolding of fusion-pediocin has not been demonstrated. Here, we report high level expression of chimeric pediocin 
Heterologous expression of pediocin PA-1 in E. coli

Table 1. Purification of rec-pediocin expressed in E. coli BL21.

\begin{tabular}{|l|c|c|c|c|c|}
\hline $\begin{array}{c}\text { Fraction } \\
\text { activity }\end{array}$ & $\begin{array}{c}\text { Total activity } \\
\left(\mathbf{A U} \mathbf{H}^{\#}\right.\end{array}$ & $\begin{array}{c}\text { Total } \\
\text { protein } \mathbf{( m g )}\end{array}$ & $\begin{array}{c}\text { Specific activity } \\
(\mathbf{A U} / \mathbf{m g})\end{array}$ & $\begin{array}{c}\text { Yield } \\
(\mathbf{\%})\end{array}$ & Fold in sp. \\
\hline Total lysate & ND & 300 & ND & - & - \\
\hline Ni-NTA Eluted & $4.5 \times 10^{5}$ & 15 & $3 \times 10^{4}$ & 100 & 1 \\
\hline RP-HPLC fraction & $2 \times 10^{5}$ & 10 & $2 \times 10^{4}$ & 83 & 1.25 \\
\hline
\end{tabular}

\#AU is defined as the mg quantity of protein require to exhibit definite zone of inhibition against the indicator bacterium as tested by spot-on-lawn assay.

*Obtained from the culture grown in 3 litre.

ND: no detection, V7 was used as an indicator strain.

PA-1 in E. coli, followed by a simple, single step purification and glycine/ $\beta$-mercaptoethanol ( $\beta-\mathrm{ME}$ ) mediated in vitro refolding of recombinant protein. This method provides sufficient pure form of protein, produced in a short time to be used for biophysical and in-vitro studies.

\section{MATERIALS AND METHODS}

\section{Bacterial strains, plasmid vectors and growth conditions}

The LAB strain of P. acidilactici K7 (Halami et al. 2005) was grown in de Man, Rogosa and Sharpe (MRS) medium (Himedia, Mumbai, India) at $37^{\circ} \mathrm{C}$. E. coli strains $\mathrm{DH} 5 \alpha$ and BL21 were grown in Luria Bertani (LB) medium (Himedia) at $37^{\circ} \mathrm{C}$ in an incubator shaker. Food-borne pathogenic strain of Listeria monocytogens V7 procured from Dr. A.K. Bhunia, Purdue University, USA was grown in Brain Heart Infusion (BHI) broth (Himedia) at $37^{\circ} \mathrm{C}$ in an incubator shaker and maintained on a BHI agar slant. For the selection and maintenance of $E$. coli plasmid vectors such as pUC19 (Gibco BRL) and pRSET-A (Invitrogen), $50 \mu \mathrm{g} \mathrm{ml}^{-1}$ ampicillin was added in LB broth and LB agar (1.2\%) media. The pUC derived recombinants were selected on LB, X-Gal, IPTG and Amp $\left(100 \mu \mathrm{g} \mathrm{ml}^{-1}\right)$ agar plate by blue/white screening.

\section{Molecular techniques and construction of pRpedA/A}

Plasmid isolation from E. coli, restriction endonucleases (Promega USA and Bangalore Genei, Bangalore India), agarose gel electrophoresis, denaturing acrylamide gel and polymerase chain reaction (PCR) were performed using standard methods (Sambrook and Russell, 2001). For elution of the DNA fragments from the agarose gel, Qiagen column (QuiQuick, Germany) was used. Plasmid DNA from $P$. acidilactici $\mathrm{K} 7$ was isolated by the method described previously (Anderson and Mckay, 1983).
For PCR cloning of the pediocin structural gene (pedA), forward primer PedA.F TTTGCCATGGAAAAAATTGAAAAATTAAC $3^{\prime}$ and reverse primer PedImm.R $5^{\prime}$ CCCTTTATCAGGATCCTTGGCTAGGCC 3' were used. These primers corresponding at positions 1065-1094 bp and 1624-1651 bp for forward and reverse primer, respectively (Marugg et al. 1992). Amplification was achieved in a thermal cycler (MWG Biotech, Germany) by 2 Units of Taq DNA polymerase (Bangalore Genei) per $50 \mu \mathrm{l}$ of reaction mixture. The PCR conditions were: initial denaturation at $95^{\circ} \mathrm{C}$ for 3 min followed by 35 cycles of denaturation at $94^{\circ} \mathrm{C}$ for $30 \mathrm{sec}$, annealing at $50^{\circ} \mathrm{C}$ for 30 sec and synthesis at $72^{\circ} \mathrm{C}$ for $1 \mathrm{~min}$. A final extension of 10 min at $72^{\circ} \mathrm{C}$ was performed. PCR products were analyzed by agarose (2\%) gel electrophoresis using a 100 bp DNA molecular size marker (MBI Fermentas). The PCR product was purified by the PCR purification kit (Qiagen) and was ligated into the T-tail (pTZ57R/T) cloning vector (MBI Fermentas) by using 3 Units of T4 DNA ligase at $22^{\circ} \mathrm{C}$ for $3 \mathrm{hrs}$. The recombinant plasmid was transformed into $E$. coli $\mathrm{DH} 5 \alpha$ and the transformants were first screened by using blue/white selection followed by restriction digestion. The recombinant plasmid pTtailAB was digested with KpnI/HindIII restriction enzymes and the 180 bp DNA fragment was eluted from the gel, purified subcloned into the KpnI/HindIII double digested vector pRSET-A. The recombinant $\mathrm{pRpedA} / \mathrm{A}$ was confirmed by double digestion with the same enzymes and nucleotide sequence analysis was achieved using the $\mathrm{T} 7$ reverse priming site at Delhi University South campus (New Delhi).

\section{Expression and purification of chimeric protein}

Recombinant plasmid pRpedA/A was transformed into protein expression host BL21 and gene expression was induced by $1 \mathrm{mM}$ IPTG and further grown for additional 4 hrs. Cells were harvested by centrifugation and cell pellet 
was washed with $0.9 \% \mathrm{NaCl}$ and resuspended in $50 \mathrm{mM}$ Tris (pH 7.5), 2 mM EDTA, 2 mM PMSF and 0.1\% Triton $\mathrm{X} 100$. The resuspended cells were disrupted by sonication (dr. Hielscher $\mathrm{GmbH}$, Germany) for $1 \mathrm{~min}$ and freeze thawed twice at $-20^{\circ} \mathrm{C}$. IBs were precipitated by centrifugation, washed with $2 \mathrm{M}$ urea and were dissolved in $6 \mathrm{M}$ urea in $25 \mathrm{mM}$ Tris in a pH range of 6 to 9 for studying solubilization patterns and absorbance was recorded at 280 $\mathrm{nm}$ by using UV-visible Spectrophotometer (Shimadzu, Japan). The solubility of IBs by the addition of dithiotritol (DTT) obtained from SRL, was studied as described by Xie et al. (1998).

The urea denatured, completely solubilized IBs were refolded as described by Eisenmesser et al. (2000). Essentially, the urea dissolved IB were suspended slowly in the refolding buffer consisting of $50 \mathrm{mM}$ Tris ( $\mathrm{pH} 7.5$ ), 50 $\mathrm{mM} \mathrm{NaCl}, 1 \mathrm{mM}$ EDTA, $1 \mathrm{M}$ glycine, $5 \mathrm{mM} \beta$-ME and 5 $\mathrm{mM}$ immidazole and stirred for $18-20 \mathrm{hrs}$ at room temperature. Any precipitate was removed by filtration through $0.45 \mu$ filter (Millipore) and the soluble fraction was mixed with refolding buffer charged $\mathrm{Ni}^{2+}$ NTA beads (Qiagen). Nickel bound proteins were removed by centrifugation and beads were washed with refolding buffer consisting of $20 \mathrm{mM}$ immidazole (SRL, India). Pure 6X His tagged proteins were eluted with $0.5 \mathrm{M}$ immidazole in refolding buffer.

\section{Preparation of native pediocin PA-1}

Native pediocin PA-1 was prepared by growing the $P$. acidilactici K7 in MRS broth. Cell-adsorption-dessorption method as described by Daba et al. (1994) was followed for concentrating bacteriocin. For subsequent purification, reverse phase HPLC was performed using the protocol described by Elegado et al. (1997). Pediocin PA-1 was purified using a semi-preparative reverse phase $\mathrm{C} 18$ column $(25 \mathrm{~cm} \times 4.6 \mu)$ in a preparative chromatography system class VP system, with automated gradient controller, gradient pumps and Spectrophotometer (LC8A, SPD-MOAVP, Shimadzu, Japan). The conditions for the gradient elution of solvent B $(99.9 \%$ acetonitrile with $0.1 \%$ TFA) against solvent $\mathrm{A}$ (water with $0.1 \%$ TFA) at a flow rate of $1.5 \mathrm{ml} \mathrm{min}^{-1}$ were as follows: 0 to $10 \mathrm{~min}, 99.7 \%$ solvent $\mathrm{A}$ and $0.3 \%$ solvent $\mathrm{B} ; 10$ to $20 \mathrm{~min} 70 \% \mathrm{~A}$ and $30 \% \mathrm{~B} ; 20$ to $30 \mathrm{~min} 40 \%$ solvent $\mathrm{B}$ and $60 \% \mathrm{~A} ; 30$ to 40 min, $40 \%$ solvent $\mathrm{B}$ and $60 \%$ solvent $\mathrm{A} ; 40$ to $50 \mathrm{~min} 50 \%$ each solvent B and A; 50 to 55 min $100 \%$ solvent B; 55 to $58 \mathrm{~min} 100 \%$ solvent A. All the protein peaks were collected manually, vacuum evaporated with a speed Vac concentrator (Biotron, ECOSPIN $3180 \mathrm{C}$ ) and subjected to bioassay to identify the pediocin PA-1 peak. Finally, the active fraction was freeze dried and stored in a vacuum dessicator prior to analysis.

\section{Biophysical characterization}

Physiochemical analysis of pure recombinant and native pediocin were carried out by UV spectrum as described by
Patra et al. (2000). The elution profile of unfolded and refolded rec-pediocin was carried out by preparative RPHPLC (Shimadzu).

\section{Pediocin PA-1 activity and protein estimation}

Antimicrobial assay was performed against $L$. monocytogenes $\mathrm{V} 7$ by using $2 \mathrm{~mm}$ filter discs. Bacteriocin activity, arbitrary unit (AU) as well as Minimum inhibitory concentration (MIC) was calculated based on the amount of protein exhibiting a definite zone of inhibition on a lawn of indicator strain V7. Refolded pediocin treated with trypsin (SRL) was used as a control. Protein estimation was carried out by Bradford method (Bradford, 1976) using BSA as a standard.

\section{RESULTS AND DISCUSSION}

\section{Construction and expression of recombinant pRpedA/A}

The 600 bp PCR amplified DNA fragment of pedAB gene was ligated into $\mathrm{T}$-tail vector and the putative recombinant was subcloned into pRSET A vector and recombinant was named as pRpedA/A. The nucleotide sequences of the recombinant revealed that the structural gene of pediocin of native strain is similar to pediocin AcH1/PA-1 (Acc. No. M83924). Further, the translated fusion construct shows restoration of the reading frame in the fusion protein where the His tag-Xpress is fused to the $\mathrm{N}$-terminal of prepediocin. Figure 1a shows the deduced amino acid sequence of the cloned and expressed pediocin fusion (recpediocin) protein. The theoretical MW of rec-pediocin is found to be $12.8 \mathrm{kDa}$ which is three times higher than the native (matured) pediocin PA-1 (Marugg et al. 1992).

The recombinant plasmid was transformed into the $E$. coli expression host BL21 and rec-pediocin expression was induced by $1 \mathrm{mM}$ IPTG for 2, 4 and 6 hrs. BL21 host transformed with only vector was taken as control. Protein from the total cell lysate was separated on a $15 \%$ denaturing gel. Overexpression of the protein of $\sim 12.8 \mathrm{kDa}$ (expected size) was observed in recombinants induced with IPTG. However, un-induced recombinant and induced control culture (having only vector) were unable to synthesize pediocin as evidenced by lack of any protein band of expected size. The precipitate obtained after centrifugation of recombinant bacterial lysate that had been induced was washed with $2 \mathrm{M}$ urea and dissolved in $6 \mathrm{M}$ urea. The protein thus solubilized contained an intense 12.8 $\mathrm{kDa}$ protein band indicating that the protein had been localized to IBs (Figure 1b). In E. coli induction with $1 \mathrm{mM}$ IPTG for $4 \mathrm{hrs}$ allowed copious accumulation of recombinant protein. Induction for longer periods or the addition of higher concentrations of inducer reduced the cell growth drastically (data not shown). For the purpose of purification of rec-pediocin, the total cell lysate of recombinant clone was incubated with Ni-NTA beads. The 6X His tagged protein was immobilized to the $\mathrm{Ni}^{2+}$ beads 


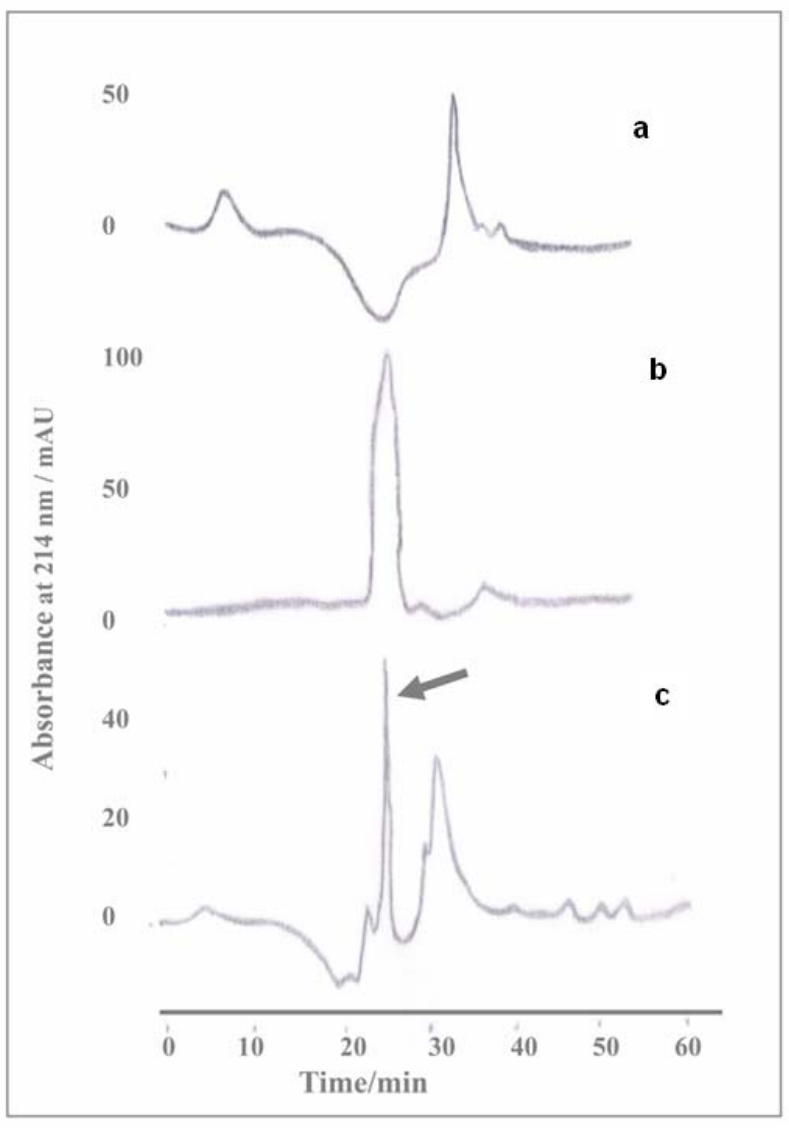

Figure 2. Semi-preparative RP-HPLC analysis of recombinant and native pediocin.

a) Unfolded.

b) Refolded rec-pediocin.

c) Pediocin preparation from native source. Arrow indicates the active pediocin PA-1 peak.

pre-equilibrated with lysis buffer. A $12.8 \mathrm{kDa}$ protein was eluted with $0.5 \mathrm{M}$ immidazole from the gel as evidenced on SDS-PAGE gel (Figure 1c, lane 3).

The properties of IBs with reference to solubility in different concentration of urea and at varying $\mathrm{pH}$ was studied. The IBs were isolated and washed with 2 to $6 \mathrm{M}$ urea and dissolved in Tris buffer $\mathrm{pH}$ ranging 6 to 9 . Increased solubility of IB with higher concentration of urea and increased reductant was found (data not shown). Solubility of IBs was further enhanced 2 fold by addition of DTT. Xie et al. (1998) have demonstrated that using 10 $\mathrm{mM}$ DTT increased the solubilization of human RBP by 2.5 fold.

\section{Protein refolding and single step purification}

In this study, we have used the additives $\beta$-ME and $1 \mathrm{M}$ glycine and affinity chromatography as aids to protein solubilization and refolding. The single step purification of rec-pediocin followed by RP-HPLC as summarized in Table 1, exhibited the biological activity of heterologously expressed rec-pediocin. About $10 \mathrm{mg}$ of protein was obtained with a specific activity of $2 \times 10^{4} \mathrm{AU} / \mathrm{mg}$. The final yield of rec-pediocin was $3 \mathrm{mg} / \mathrm{l}$ of the initial culture taken and this yield was found to be 8-10 times higher than conventional method of protein purification. It has been previously suggested that the choice of refolding buffer and immobilization on Ni-NTA beads itself facilitates in renaturation of proteins (Rogl et al. 1998). The thiol compound such as $\beta$-ME at a concentration of 5-15 mM have been found to act as a oxido-shuffling agents during renaturation and disulfide bond formation. The low MW additive, such as glycine help reduce protein aggregation during the refolding process (De Bernardez Clark, 2001). Eisenmesser et al. (2000) used either $5 \mathrm{mM} \beta$-ME or $1 \mathrm{mM}$ oxidized glutathione redox buffer as a reducing agent along with $1 \mathrm{M}$ glycine. The latter helped to increase the yield of refolding fusion protein of IL-13 by a factor of two.

\section{Properties of rec-pediocin}

In a preparative RP-HPLC, refolded rec-pediocin was eluted as a single major peak at $20 \mathrm{~min}$. However, the unfolded fraction showed late elution of major peak at 30 min. The single peak of refolded rec-pediocin was comparable with the active fraction of native pediocin, which was shown to have a similar pattern of retention (Figure 2). This eluted fraction was capable of inhibiting the growth of L. monocytogenes $\mathrm{V} 7$ indicating that the chimeric pediocin PA-1 had refolded to its active confirmation in the refolding buffer. When this fraction was treated with trypsin, reduced zone of inhibition was seen. The unfolded rec-pediocin was unable to exhibit the antimicrobial activity, since the major peak of RP-HPLC did not show inhibition (data not shown). The MIC of native pediocin PA-1 was $2 \mathrm{ng}$ while for rec-pediocin, it was $50 \mathrm{ng}$ against strain V7. This value suggested recpediocin was at least 25 times less active than its native counterpart. Comparison of the two proteins needs to be repeated taking into account yield and protein content. Human proinsulin obtained from IBs of E. coli was renatured in presence of suitable redox conditions, renatured and denatured proinsulin was characterized by RP-HPLC and comparison with native insulin was made (Winter et al. 2002b). In the present study, a similar strategy was adopted to analyze unfolded and refolded pediocin by RP-HPLC followed by antimicrobial assay. The refolding agents such as glutathione, cyteine-cystine etc provides reducing environment that subsequently assist in formation of disulfide-bridges. Refolding additives such as L-arginine or glycine that work as aggregation suppressors can also enhance the yield of renaturation. In our experiment, use of $1 \mathrm{M}$ glycine was found to be useful in combination with a thiol compound (data not shown).

In the present study, slow dilution of urea solubilized IBs in a refolding buffer consisting of $\beta$-ME along with glycine assisted in proper folding of the rec-pediocin in its proper secondary structure. The $\beta-\mathrm{ME}$ has a redox potential of $E^{\mathrm{o}}$ $=-0.26$ involved in thiol disulfide interchange reaction associated with renaturation of protein (Lees and 
Whitesides, 1993). Winter et al. (2002a) demonstrated the use of synthetic dithiol vectrase-P stimulates in vitro folding of proinsulin. The vectrase-P with a redox potential of $E^{\mathrm{o}}=-0.24 \mathrm{~V}$ is known to be more oxidizing than $\beta$-ME. This step was further combined with Ni-NTA purification that had an added effect on refolding of the protein (Rogl et al. 1998). Further purification of rec-pediocin was also carried out by RP-HPLC after elution from Ni-NTA beads. RP-HPLC assisted in studying the elution profile of refolded protein in comparison with denatured recpediocin. The UV absorption spectrum scanned between $190 \mathrm{~nm}$ and $350 \mathrm{~nm}$ of the purified rec-pediocin was compared with that of native pediocin PA-1. The absorbance maxima of the recombinant and native pediocin PA-1 differed in the shoulder at around $220 \mathrm{~nm}$. The difference may be attributed to the N-terminal extension of prepeptide sequence and the tag. However, common overlapping peaks were seen for both proteins at $190 \mathrm{~nm}$. Previously, Patra et al. (2000) had used spectroscopic analysis to study refolding of r-hGH. By comparing pure r$\mathrm{hGH}$ and the native hGH, it was seen that the absorbance maxima of the purified r-hGH was at $276.8 \mathrm{~nm}$ with a shoulder at $283 \mathrm{~nm}$.

Since pediocin PA-1 represents class IIa bacteriocin with a strong antilisterial activity, the major application of this bacteriocin is in biopreservation. Conventional procedures for its production in large scale are cumbersome and time consuming and hence necessitated for the development of an easier method of production. In recent years, divericin and His-tag pediocin PA-1 have been expressed in E. coli and purification was achieved by Ni-NTA affinity chromatography. However, total yield was limited due to low level of expression. In certain cases, pediocin has been expressed in culture filtrate, however, due to poor secretion property of $E$. coli, this was not achieved in a large scale. The chimeric pediocin PA-1 can be expressed in large quantity and recovered from IBs, solubilized and refolded in to its biologically active form using cheaper refolding agent that are described in this study.

\section{ACKNOWLEDGMENTS}

Authors wishes sincere gratitude to the Director of the institute for the facilities. We thank Head of the Department of Food Microbiology for his interest in this work and for his constant support and encouragement. We are grateful to the unknown reviewer/s for their kind suggestions in the improvement of the manuscript to the present form.

\section{REFERENCES}

ANDERSON, Douglas G. and MCKAY, Larry L. Simple and rapid method for isolating large plasmid DNA from lactic streptococci. Applied and Environmental Microbiology, September 1983, vol. 46, no. 3, p. 549-552.

AXELSSON, Lars; KATLA, Tone; BJORNSLETT, Merete; EIJSINK, Vincent G.H. and HOLCK, Askild. A system for heterologous expression of bacteriocins in Lactobacillus sake. FEMS Microbiology Letters, November 1998, vol. 168, no. 1, p. 137-143.

BEAULIEU, Lucie; GROLEAU, Denis; MIGUEZ, Carlos B.; JETTE, Jean-François; AOMARI, Hafida and SUBIRADE, Muriel. Production of pediocin PA-1 in the methylotrophic yeast Pichia pastoris reveals unexpected inhibition of its biological activity due to the presence of collagen-like material. Protein Expression and Purification, October 2005, vol. 43, no. 2, p. 111-125.

BRADFORD, M.M. A rapid and sensitive method for the quantitation of microgram quantities of protein utilizing the principle of protein-dye binding. Analytical Biochemistry, May 1976, vol. 72, no. 1-2, p. 248-254.

CODERRE, P.E. and SOMKUTI, G.A. Cloning and expression of the pediocin operon in Streptococcus thermophilus and other lactic fermentation bacteria. Current Microbiology, November 1999, vol. 39, no. 5, p. 295-301.

DABA, H.; LACROIX, C.; HUANG, J.; SIMARD, R.E. and LEMIEUX, L. Simple method of purification and sequencing of a bacteriocin produced by Pediococcus acidilactici UL5. Journal of Applied Bacteriology, 1994, vol. 77, no. 6, p. 682-688.

DE BERNARDEZ CLARK, Eliana. Protein refolding for industrial processes. Current Opinion in Biotechnology, April 2001, vol. 12, no. 2, p. 202-207.

EISENMESSER, Elan Zohar; KAPUST, Rachel B.; NAWROCKI, Joseph P.; MAZZULLA, Marie J.; PANNELL, Lewis K.; WAUGH, David S. and BYRD, R. Andrew. Expression, purification, refolding, and characterization of recombinant human interleukin-13: utilization of intracellular processing. Protein Expression and Purification, November 2000, vol. 20, no. 2, p. 186195.

ELEGADO, Francisco B.; KIM, Wang June and KWON, Dae Young. Rapid purification, partial characterization, and antimicrobial spectrum of the bacteriocin, Pediocin AcM, from Pediococcus acidilactici M. International Journal of Food Microbiology, June 1997, vol. 37, no. 1, p. 1-11.

HALAMI, P.M.; RAMESH, A. and CHANDRASHEKAR, A. Fermenting cucumber, a potential source for the isolation of pediocin-like bacteriocin producers. World Journal of Microbiology and Biotechnology, December 2005, vol. 21, no. 8-9, p. 1351-1358.

LEES, Watson J. and WHITESIDES, George M. Equilibrium constants for thiol-disulfide interchange reactions: A coherent, corrected set. Journal of Organic Chemistry, 1993, vol. 58, no. 3, p. 642-647. 
MAKRIDES, S.C. Strategies for achieving high-level expression of genes in Escherichia coli. Microbiology and Molecular Biology Reviews, September 1996, vol. 60, no. 3 , p. $512-538$.

MARUGG, Joey D.; GONZALEZ, Carlos F.; KUNKA, Blair S.; LEDEBOER, Aat M.; PUCCI, Michael J.; TOONEN, Marjolein Y.; WALKER, Shirley A.; ZOETMULDER, Leonie C. and VANDENBERGH, Peter A. Cloning, expression and nucleotide sequence of genes involved in production of pediocin PA-I, a bacteriocin from Pediococcus acidilactici PAC1.0. Applied and Environmental Microbiology, August 1992, vol. 58, no. 8, p. $2360-2367$.

MILLER, Kurt W.; SCHAMBER, Robin; CHEN, Yanling and RAY, Bibek. Production of active chimeric pediocin $\mathrm{AcH}$ in Escherichia coli in the absence of processing and secretion genes from the Pediococcus pap operon. Applied and Environmental Microbiology, January 1998, vol. 64, no. 1, p. 14-20.

MOON, Gi-Seong; PYUN, Yu-Ryang; PARK, Myeong Soo; JI, Geun Eog and KIM, Wang June. Secretion of recombinant pediocin PA-1 by Bifidobacterium longum, using the signal sequence for Bifidobacterial $\alpha$-amylase. Applied and Environmental Microbiology, September 2005, vol. 71, no. 9, p. 5630-5632.

MOON, Gi-Seong; PYUN, Yu-Ryang and KIM, Wang June. Expression and purification of a fusion-typed pediocin PA-1 in Escherichia coli and recovery of biologically active pediocin PA-1. International Journal of Food Microbiology, April 2006, vol. 108, no. 1, p. 136-140.

PATRA, A.K.; MUKHOPADHYAY, R.; MUKHIJA, R.; KRISHNAN, A.; GARG, L.C. and PANDA, A.K. Optimization of inclusion body solubilization and renaturation of recombinant human growth hormone from Escherichia coli. Protein Expression and Purification, March 2000, vol. 18, no. 2, p. 182-192.

RAY, Bibek; SCHAMBER, Robin and MILLER, Kurt W. The pediocin AcH precursor is biologically active. Applied and Environmental Microbiology, June 1999, vol. 65, no. 6, p. 2281-2286.

REVIRIEGO, C.; FERNANDEZ, A.; HORN, N.; RODRIGUEZ, E.; MARIN, M.L.; FERNANDEZ, L. and RODRIGUEZ, J.M. Production of pediocin PA-1, and coproduction of nisin A and pediocin PA-1, by wild Lactococcus lactis strains of dairy origin. International Dairy Journal, January 2005, vol. 15, no. 1, p. 45-49.

RICHARD, Christelle; DRIDER, Djamel; ELMORJANI, Khalil; MARION, Didier and PREVOST, Hervé. Heterologous expression and purification of active divericin V41, a class IIa bacteriocin encoded by a synthetic gene in Escherichia coli. Journal of Bacteriology, July 2004, vol. 186, no. 13, p. 4276-4282.
RODRIGUEZ, J.M.; MARTINEZ, M.I.; HORN, N. and DODD, H.M. Heterologous production of bacteriocins by lactic acid bacteria. International Journal of Food Microbiology, January 2003, vol. 80, no. 2, p. 101-116.

ROGL, H.; KOSEMUND, K.; KUHLBRANDT, W. and COLLINSON, I. Refolding of Escherichia coli produced membrane protein inclusion bodies immobilized by nickel chelating chromatography. FEBS Letters, July 1998, vol. 432, no. 1-2, p. 21-26.

SAMBROOK, Joseph and RUSSELL, David W. Molecular cloning: A laboratory manual. $3^{\text {rd }}$ ed. Cold Spring Harbor Laboratory, Cold Spring Harbor, NY, 2001, vol. 2. ISBN 087-969577-3.

SCHOEMAN, Heidi; VIVIER, Melané A.; TOIT, Maret $\mathrm{du}$; DICKS, Leon M.T. and PRETORIUS, Isak S. The development of bactericidal yeast strains by expressing the Pediococcus acidilactici pediocin gene (pedA) in Saccharomyces cerevisiae. Yeast, June 1999, vol. 15, no. 8, p. 647-656.

SOMKUTI, G.A. and STEINBERG, D.H. Pediocin production by recombinant lactic acid bacteria. Biotechnology Letters, March 2003, vol. 25, no. 6, p. 473477.

STEIN, Torsten; HEINZMANN, Stefan; SOLOVIEVA, Irina and ENTIAN, Karl-Dieter. Function of Lactococcus lactis nisin immunity genes nisI and nisFEG after coordinated expression in the surrogate host Bacillus subtilis. Journal of Biological Chemistry, January 2003, vol. 278 , no. 1 , p. 89-94.

WINTER, Jeannette; LILIE, Hauke and RUDOLPH, Rainer. Recombinant expression and in vitro folding of proinsulin are stimulated by the synthetic dithiol vectrase-P. FEMS Microbiology Letters, August 2002a, vol. 213, no. 2, p. 225-230.

WINTER, Jeannette; LILIE, Hauke and RUDOLPH, Rainer. Renaturation of human proinsulin-a study on refolding and conversion to insulin. Analytical Biochemistry, November 2002b, vol. 310, no. 2, p. 148155 .

XIE, Yansheng; LASHUEL, Hilal A.; MIROY, Greta J.; DIKLER, Sergei and KELLY, Jeffery W. Recombinant human retinol-binding protein refolding, native disulfide formation, and characterization. Protein Expression and Purification, October 1998, vol. 14, no. 1, p. 31-37. 